\title{
MBA Student And Alumni Ratings Of Critical Skills In Graduate Business Programs
}

Joseph G. Glynn, (Email: glynn@ canisius.edu), Canisius College Richard A. Shick, (Email: shick@canisius.edu), Canisius College

\begin{abstract}
Newly matriculating MBAs, recent MBA graduates, and MBA alumni were surveyed with respect to program and curriculum issues and opinions concerning nine skills deemed to be critical for graduate business education. At the time of matriculation, MBA students were surveyed concerning how important the skills were to them. The students were also surveyed immediately after graduation, and asked how successful the program had been in developing these skills. The final analysis group was MBA alumni who were asked to identify the most improved and most important skills. Between-group comparisons of results concerning these nine skills will be presented along with other results reflecting evaluations of program attributes.
\end{abstract}

\section{INTRODUCTION}

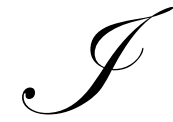

$t$ is extremely important for MBA Programs to practice the principles they teach when it comes to factors like measuring the quality of the program, the success in delivering the program, the educational needs of the market place, and the changing demographics of the market. Continuous improvement must be a way of life if a program is to be successful. The Richard J. Wehle School of Business established a series of survey instruments many years ago to assess these factors and this paper will report the results of this work over the period 1997-2004.

Previous studies have reported results from the surveys administered to new MBA matriculates (Glynn 2004) and graduating MBAs (Glynn 2005). Portions of those works will be replicated here. The major purpose of this paper is to compare and contrast the opinions of three groups of survey respondents - the two groups previously reported, and the MBA alumni. These comparisons reveal interesting changes in student demographics, the importance they attach to various program goals and attributes, and the trends in the importance of these factors. In the material that follows we will look at the changing demographics of our students, the reasons they chose our MBA Program, satisfaction with their education, and the factors they consider important in a graduate education.

\section{SOME BACKGROUND ON THE SCHOOL AND ITS MBA PROGRAM}

The Richard J. Wehle School of Business is one of three divisions of Canisius College. Canisius is among the 28 Jesuit colleges and universities in the United States. It was established in 1870 and has been offering programs in business since the early 1900s. The Wehle School was officially established as a separate division of the College in 1957 and named for a local entrepreneur in 1989. The school was first accredited by AACSB International in 1977. There is both an undergraduate and a graduate division. The undergraduate division offers seven majors and the graduate division offers four programs - a full-time one-year MBA and part-time evening MBA programs including two MBAs in accounting.

The data for this study come from students and graduates of the part-time evening programs. There are approximately 230 students currently enrolled in these programs. They live in the immediate geographical area and about $80 \%$ are employed full-time. A large number of students receive some form of tuition reimbursement from their 
employers. There is very little student financial aid available from the college. Classes for the part-time programs are taught on the main campus and at a satellite site that was established in a suburban office park about 10 years ago. This site has become very popular with the students due to its convenient location and state-of-the-art classroom facilities.

The part-time MBA Program was extensively revised in 1995, a date which also marks the initiation of the current student survey project. The MBA Program was revised again in 2002 to give students the opportunity to concentrate in one or more of several areas of study. Currently the most popular areas are finance (31\%) and marketing (28\%). There is a growing interest in international business.

\section{DESCRIPTIVE BACKGROUND RESULTS}

Results in this work will be reported for the following three graduate business student groups:

- $\quad$ New MBA matriculates - this group was surveyed during new student orientation, or via a survey mailed during the first week of classes.

- $\quad$ Recent MBA Graduates - these students were mailed a survey and follow-up letter within weeks of graduation.

- $\quad$ MBA Alumni - alumni were surveyed four years after graduation.

In order to provide some basic familiarity with the graduate business students at our college and some of the issues pertinent to their views relating to the value of graduate business education, background data with respect to the following dimensions are presented in Tables 1 through 4.

- demographics and professional profiles of new matriculates,

- reasons new matriculates chose our program,

- $\quad$ recent graduates' ratings of various aspects and attributes of our program, and

- $\quad$ reasons MBA alumni would recommend our program.

New Matriculate Student Profiles

Profiles of our newly matriculating MBA students are presented in Table 1 below. There are some interesting trends in the data. The percentage of females declined in the early 2000s, but has come back in 2004 . During this same period the college's graduate education programs grew rapidly suggesting that more women may have gone into teaching careers. That growth has begun to slow, there are fewer teaching positions available in the area and women may be returning to business. The percentage of students under 25 years of age has grown while the percentage of students employed full-time has declined somewhat. The student body is getting younger with more students apparently going directly from undergraduate to graduate school. This trend may be the result of dual degree programs the college has developed to encourage students to earn an undergraduate and a graduate degree at the same time. In addition, local economic conditions have resulted in the loss of jobs for individuals with work experience. Thus the students who remain may be completing their education before leaving the area. We consider it very important to keep a close eye on any trends that may be developing on any of these items.

\section{Reasons New Matriculates Chose Our Program}

Newly matriculating students were asked to rate the importance of eight items representing reasons students may have chosen our MBA Program. The items were rated on a scale from 1 (Not Important) to 7 (Very Important). Each cell of Table 2 contains: the mean or average rating on the seven-point scale, the number of respondents $(\mathrm{n})$, the standard deviation (s) of the rating on the seven-point scale, and the percent of respondents (MI\%) who rated the item as the most important reason they chose our MBA Program. 
Table 1

Descriptive Student Profiles Of New Matriculates

\begin{tabular}{|c|c|c|c|c|c|c|c|c|c|c|}
\hline $\begin{array}{l}\text { Student } \\
\text { Characteristic }\end{array}$ & & 1997 & 1998 & 1999 & 2000 & 2001 & 2002 & 2003 & 2004 & Total \\
\hline Gender & $\begin{array}{c}\text { Female } \\
\text { Male }\end{array}$ & $\begin{array}{l}50.8 \% \\
49.2 \%\end{array}$ & $\begin{array}{l}31.6 \% \\
68.4 \%\end{array}$ & $\begin{array}{l}54.8 \% \\
45.2 \%\end{array}$ & $\begin{array}{l}52.4 \% \\
47.6 \%\end{array}$ & $\begin{array}{l}46.8 \% \\
53.2 \%\end{array}$ & $\begin{array}{l}42.9 \% \\
57.1 \%\end{array}$ & $\begin{array}{l}41.8 \% \\
58.2 \%\end{array}$ & $\begin{array}{l}49.0 \% \\
51.0 \%\end{array}$ & $\begin{array}{l}46.3 \% \\
53.7 \%\end{array}$ \\
\hline Age & $\begin{array}{l}\leq 25 \\
26-35 \\
\geq 36\end{array}$ & $\begin{array}{c}27.4 \% \\
62.9 \% \\
9.7 \% \\
\end{array}$ & $\begin{array}{l}31.6 \% \\
55.3 \% \\
13.2 \% \\
\end{array}$ & $\begin{array}{c}34.9 \% \\
55.8 \% \\
9.3 \% \\
\end{array}$ & $\begin{array}{l}40.5 \% \\
45.3 \% \\
14.3 \% \\
\end{array}$ & $\begin{array}{l}38.7 \% \\
40.3 \% \\
21.0 \% \\
\end{array}$ & $\begin{array}{l}42.6 \% \\
45.9 \% \\
11.5 \% \\
\end{array}$ & $\begin{array}{l}40.9 \% \\
39.4 \% \\
19.7 \% \\
\end{array}$ & $\begin{array}{l}40.0 \% \\
44.0 \% \\
16.0 \% \\
\end{array}$ & $\begin{array}{l}37.3 \% \\
48.1 \% \\
14.6 \% \\
\end{array}$ \\
\hline UG Major & $\begin{array}{l}\text { Bus/Econ } \\
\text { Other }\end{array}$ & $\begin{array}{l}59.7 \% \\
40.3 \% \\
\end{array}$ & $\begin{array}{l}54.0 \% \\
46.0 \% \\
\end{array}$ & $\begin{array}{l}65.9 \% \\
34.1 \% \\
\end{array}$ & $\begin{array}{l}47.7 \% \\
52.3 \% \\
\end{array}$ & $\begin{array}{l}56.3 \% \\
43.7 \% \\
\end{array}$ & $\begin{array}{l}50.8 \% \\
49.2 \% \\
\end{array}$ & $\begin{array}{l}61.2 \% \\
38.8 \% \\
\end{array}$ & $\begin{array}{l}44.0 \% \\
56.0 \% \\
\end{array}$ & $\begin{array}{l}55.2 \% \\
44.8 \% \\
\end{array}$ \\
\hline $\begin{array}{l}\text { Percent of } \\
\text { Tuition } \\
\text { Reimbursed } \\
\text { By Employer }\end{array}$ & $\begin{aligned} & \text { None } \\
& \approx 25 \% \\
& \approx 50 \% \\
& \approx 75 \% \\
& \approx 100 \%\end{aligned}$ & $\begin{array}{c}\text { Data } \\
\text { Not } \\
\text { Avail. }\end{array}$ & $\begin{array}{c}23.3 \% \\
0.0 \% \\
3.3 \% \\
10.0 \% \\
63.3 \% \\
\end{array}$ & $\begin{array}{c}18.2 \% \\
6.1 \% \\
15.2 \% \\
9.1 \% \\
51.5 \% \\
\end{array}$ & $\begin{array}{c}25.0 \% \\
12.5 \% \\
0.0 \% \\
28.1 \% \\
34.4 \% \\
\end{array}$ & $\begin{array}{c}21.3 \% \\
6.4 \% \\
10.6 \% \\
14.9 \% \\
46.8 \% \\
\end{array}$ & $\begin{array}{c}20.8 \% \\
11.3 \% \\
5.7 \% \\
9.4 \% \\
52.8 \% \\
\end{array}$ & $\begin{array}{c}36.2 \% \\
4.3 \% \\
0.0 \% \\
14.9 \% \\
44.7 \% \\
\end{array}$ & $\begin{array}{c}29.7 \% \\
2.7 \% \\
8.1 \% \\
2.7 \% \\
56.8 \% \\
\end{array}$ & $\begin{array}{c}25.1 \% \\
6.5 \% \\
6.1 \% \\
12.5 \% \\
49.8 \% \\
\end{array}$ \\
\hline $\begin{array}{l}\text { Employment } \\
\text { Status }\end{array}$ & $\begin{array}{c}\text { Full-time } \\
\text { Part-time } \\
\text { Unemployed }\end{array}$ & $\begin{array}{c}88.7 \% \\
1.6 \% \\
9.7 \% \\
\end{array}$ & $\begin{array}{c}86.5 \% \\
5.4 \% \\
8.1 \% \\
\end{array}$ & $\begin{array}{c}81.8 \% \\
13.6 \% \\
4.5 \% \\
\end{array}$ & $\begin{array}{c}78.0 \% \\
2.4 \% \\
19.5 \% \\
\end{array}$ & $\begin{array}{c}77.4 \% \\
9.7 \% \\
13.0 \% \\
\end{array}$ & $\begin{array}{c}88.7 \% \\
1.6 \% \\
9.6 \% \\
\end{array}$ & $\begin{array}{c}75.0 \% \\
7.8 \% \\
17.2 \% \\
\end{array}$ & $\begin{array}{c}77.1 \% \\
6.3 \% \\
16.7 \% \\
\end{array}$ & $\begin{array}{c}81.7 \% \\
6.0 \% \\
12.4 \% \\
\end{array}$ \\
\hline $\begin{array}{l}\text { Management } \\
\text { Level of } \\
\text { Position In } \\
\text { Organization }\end{array}$ & $\begin{array}{c}\text { Upper } \\
\text { Middle } \\
\text { Supervisory } \\
\text { Non-Mgt. }\end{array}$ & $\begin{array}{l}1.9 \% \\
27.8 \% \\
11.1 \% \\
59.3 \%\end{array}$ & $\begin{array}{c}6.3 \% \\
25.0 \% \\
21.9 \% \\
46.9 \% \\
\end{array}$ & $\begin{array}{c}2.9 \% \\
17.1 \% \\
20.0 \% \\
60.0 \%\end{array}$ & $\begin{array}{c}7.1 \% \\
25.0 \% \\
14.3 \% \\
53.6 \%\end{array}$ & $\begin{array}{l}4.4 \% \\
20.0 \% \\
13.3 \% \\
62.2 \% \\
\end{array}$ & $\begin{array}{c}3.8 \% \\
17.3 \% \\
9.6 \% \\
69.2 \% \\
\end{array}$ & $\begin{array}{c}6.3 \% \\
25.0 \% \\
6.3 \% \\
62.5 \% \\
\end{array}$ & $\begin{array}{c}5.6 \% \\
30.6 \% \\
13.9 \% \\
50.0 \%\end{array}$ & $\begin{array}{l}4.5 \% \\
23.3 \% \\
13.0 \% \\
59.1 \%\end{array}$ \\
\hline
\end{tabular}

Table 2

New Matriculate Ratings Of Attributes Concerning Choice Of Program [1=Not Important ... 7=Very Important]

\begin{tabular}{|c|c|c|c|c|c|c|c|c|c|c|}
\hline Attribute & & 1997 & 1998 & 1999 & 2000 & 2001 & 2002 & 2003 & 2004 & Totals \\
\hline Program & mean & 6.05 & 5.61 & 6.02 & 6.05 & 6.08 & 6.03 & 6.22 & 5.88 & 6.02 \\
\hline \multirow[t]{3}{*}{ Reputation } & $\mathrm{n}$ & 63 & 38 & 44 & 42 & 62 & 63 & 67 & 51 & 430 \\
\hline & S & 1.22 & 1.33 & 1.15 & 1.01 & 0.93 & 1.09 & 0.90 & 1.05 & 1.08 \\
\hline & $* \mathrm{MI} \%$ & $34.4 \%$ & $40.5 \%$ & $33.3 \%$ & $40.5 \%$ & $39.3 \%$ & $44.4 \%$ & $53.7 \%$ & $34.7 \%$ & $40.7 \%$ \\
\hline Flexibility & mean & 5.77 & 5.42 & 5.98 & 6.07 & 6.05 & 6.14 & 6.15 & 6.20 & 6.00 \\
\hline Taking & $\mathrm{n}$ & 62 & 38 & 45 & 42 & 62 & 63 & 68 & 51 & 431 \\
\hline \multirow[t]{2}{*}{ Courses } & $\mathrm{s}$ & 1.31 & 1.31 & 1.18 & 1.05 & 0.95 & 0.95 & 1.00 & 1.13 & 1.12 \\
\hline & $* \mathrm{MI} \%$ & $8.2 \%$ & $32.4 \%$ & $20.0 \%$ & $26.2 \%$ & $23.0 \%$ & $30.2 \%$ & $14.9 \%$ & $24.5 \%$ & $21.6 \%$ \\
\hline AACSB & mean & 6.05 & 5.50 & 5.55 & 5.45 & 5.82 & 5.79 & 5.97 & 5.88 & 5.79 \\
\hline \multirow[t]{3}{*}{ Accreditation } & $\mathrm{n}$ & 62 & 38 & 44 & 42 & 62 & 63 & 67 & 50 & 428 \\
\hline & $\mathrm{s}$ & 1.26 & 1.52 & 1.73 & 1.78 & 1.37 & 1.59 & 1.33 & 1.53 & 1.50 \\
\hline & $* \mathrm{MI} \%$ & $24.6 \%$ & $13.5 \%$ & $20.0 \%$ & $14.3 \%$ & $16.4 \%$ & $9.5 \%$ & $10.4 \%$ & $14.3 \%$ & $15.3 \%$ \\
\hline Individual & mean & 5.29 & 4.68 & 5.45 & 5.55 & 5.73 & 5.59 & 5.76 & 5.30 & 5.46 \\
\hline \multirow[t]{2}{*}{ Attention } & $\mathrm{n}$ & 62 & 38 & 44 & 42 & 62 & 63 & 67 & 50 & 428 \\
\hline & $* \mathrm{MI} \%$ & $3.3 \%$ & $0.0 \%$ & $4.4 \%$ & $2.4 \%$ & $3.3 \%$ & $0.0 \%$ & $4.5 \%$ & $4.1 \%$ & $2.8 \%$ \\
\hline \multirow{4}{*}{$\begin{array}{l}\text { Small Class } \\
\text { Size }\end{array}$} & mean & 5.32 & 4.84 & 5.18 & 5.36 & 5.44 & 5.37 & 5.58 & 5.20 & 5.32 \\
\hline & $\mathrm{n}$ & 62 & 38 & 44 & 42 & 62 & 63 & 67 & 50 & 428 \\
\hline & S & 1.24 & 1.79 & 1.28 & 1.27 & 1.26 & 1.48 & 1.57 & 1.64 & 1.45 \\
\hline & $* \mathrm{MI} \%$ & $4.9 \%$ & $5.4 \%$ & $4.4 \%$ & $0.0 \%$ & $4.9 \%$ & $4.8 \%$ & $6.0 \%$ & $8.2 \%$ & $4.9 \%$ \\
\hline \multirow{4}{*}{$\begin{array}{l}\text { Diversity } \\
\text { Of Course } \\
\text { Offerings }\end{array}$} & mean & 5.34 & 4.89 & 4.80 & 5.40 & 5.52 & 5.30 & 5.55 & 5.26 & 5.30 \\
\hline & $\mathrm{n}$ & 62 & 37 & 44 & 42 & 62 & 63 & 67 & 50 & 427 \\
\hline & $\mathrm{S}$ & 1.23 & 1.37 & 1.29 & 1.17 & 1.11 & 1.12 & 1.15 & 1.31 & 1.22 \\
\hline & * MI \% & $0.0 \%$ & $0.0 \%$ & $0.0 \%$ & $4.8 \%$ & $4.9 \%$ & $4.8 \%$ & $0.0 \%$ & $2.0 \%$ & $2.1 \%$ \\
\hline \multirow{4}{*}{$\begin{array}{l}\text { Convenience } \\
\text { Of Satellite } \\
\text { Campus }\end{array}$} & mean & 5.03 & 5.03 & 4.86 & 4.90 & 5.21 & 4.92 & 4.94 & 4.69 & 4.96 \\
\hline & $\mathrm{n}$ & 62 & 37 & 44 & 42 & 61 & 63 & 67 & 51 & 427 \\
\hline & S & 2.00 & 2.12 & 2.09 & 2.18 & 1.78 & 1.98 & 1.86 & 2.16 & 1.99 \\
\hline & * MI \% & $13.1 \%$ & $2.7 \%$ & $8.9 \%$ & $2.4 \%$ & $1.6 \%$ & $3.2 \%$ & $1.5 \%$ & $2.0 \%$ & $4.5 \%$ \\
\hline
\end{tabular}




\begin{tabular}{|l|c|c|c|c|c|c|c|c|c|c|}
\hline Convenience & mean & 3.65 & 3.71 & 4.23 & 4.52 & 4.60 & 4.68 & 4.63 & 4.24 & 4.31 \\
Of Main & $\mathrm{n}$ & 62 & 38 & 44 & 42 & 60 & 63 & 68 & 50 & 427 \\
Campus & $\mathrm{s}$ & 1.96 & 2.09 & 1.93 & 1.99 & 1.89 & 1.48 & 1.83 & 2.05 & 1.91 \\
& $*$ MI \% & $1.6 \%$ & $0.0 \%$ & $2.2 \%$ & $0.0 \%$ & $1.6 \%$ & $0.0 \%$ & $1.5 \%$ & $0.0 \%$ & $0.9 \%$ \\
\hline
\end{tabular}

$*$ MI $\%=$ Percent of respondents who identified this attribute as being the Most Important

Table 2 presents the eight items in descending order by total mean value. Program Reputation was the highest rated attribute with an overall average of 6.02, and was closely followed by Flexibility Taking Courses (6.00) and AACSB Accreditation (5.79). The program reputation and AACSB factors may be closely related and probably are proxies for program quality. It is likely that the flexibility factor scored highly because one of the program's major competitors has a lock-step curriculum. The "quality dimensions" Program Reputation and AACSB Accreditation were more important than the "comfort dimensions" of Individual Attention (5.46), Small Class Size (5.32) and Diversity of Course Offerings (5.30). The factors of convenience of location were the lowest ranked. Interestingly the convenience of the satellite campus dominated the convenience of the main campus in the early years, but the scores have become closer in recent years. This may be the result of changing work locations for our students. Recall that the most popular concentration is finance and the head offices of the major area banks are located closer to the main campus.

These newly matriculating MBA students were also asked to identify the most important reason they chose our program. These data are reported in Table 2 as "MI \%" (Most Important Percent). The first three attributes Program Reputation, Flexibility Taking Courses, and AACSB Accreditation - dominated as the most important reasons for choice of our program. A cumulative total of 77.6 percent of new matriculates named one of these three as being most important. Note that the percents in any column of Table 2 do not sum to 100 percent due to the fact that an open-end "Other" response was allowed, but is not herein reported.

\section{Recent Graduates Evaluate Various Aspects of Graduate Business Program}

Our recent graduates, who were surveyed within weeks of graduation, are a rich source of very important information. Having just graduated, their opinions and perceptions concerning their experiences are vital to our understanding of issues that both affect and motivate our students. The graduating students were asked to "rate the following aspects of the Graduate Business Program from 1 (Poor) to 7 (Excellent)." We were interested in their evaluations along several dimensions including: quality of faculty, curriculum, educational delivery systems, and physical resources.

Twenty-seven items or program attributes were included on the list to be evaluated by our students. Results for 24 of these items are reported in Table 3 (the items omitted from Table 3 concerned audio visual equipment, and two parking items). The attributes have been ordered in Table 3 from highest-rated to lowest-rated on the basis of total average rating over the eight-year time horizon.

As might be expected, the students' attention has shifted from program reputation when they began their studies to the operating elements of the program. The highest ratings were given to Classroom Facilities at our relatively new satellite campus and Size of Classes. The appreciation of small class sizes is not at all surprising, and would likely be a positive attribute in all MBA programs. The new satellite campus is extremely popular with our graduate students for a variety of reasons including:

- $\quad$ ease of parking,

- $\quad$ large classrooms with comfortable furniture and movable tables which can accommodate a variety of lecture/presentation formats,

- $\quad$ a modern well equipped computer lab that also serves as a classroom, and

- great location near two freeways in a large suburb that serves as home to an expanding professional class of residents and businesses. 
The faculty should be well encouraged by the high ratings of the next five attributes:

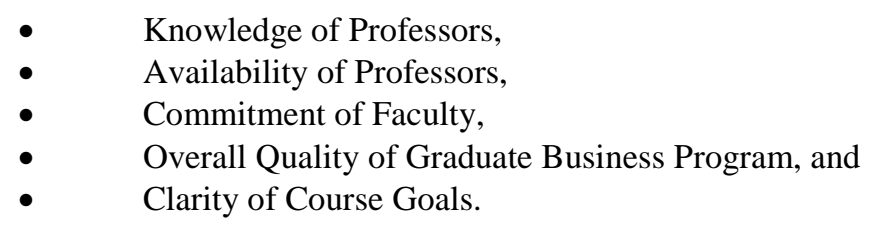

Indeed, the first 20 attributes, down to and including Integration of Material Between Courses, were consistently rated highly having attained an average above five on the seven-point scale. Finally, it is noteworthy that even the lowest rated item, Classroom Facilities (Main Campus), achieved a slightly positive overall average rating of 4.19 .

Table 3

Recent Graduate Ratings Of Graduate Business Program Attributes [1=Poor ... 7=Excellent

\begin{tabular}{|c|c|c|c|c|c|c|c|c|c|c|}
\hline Attribute & & 1997 & 1998 & 1999 & 2000 & 2001 & 2002 & 2003 & 2004 & Totals \\
\hline $\begin{array}{l}\text { Classroom Facilities } \\
\text { (Satellite Campus) }\end{array}$ & $\begin{array}{c}\text { mean } \\
\mathrm{n}\end{array}$ & $\begin{array}{c}6.43 \\
53\end{array}$ & $\begin{array}{c}6.39 \\
62\end{array}$ & $\begin{array}{c}6.50 \\
36\end{array}$ & $\begin{array}{c}6.24 \\
46\end{array}$ & $\begin{array}{c}6.37 \\
63\end{array}$ & $\begin{array}{c}6.00 \\
36\end{array}$ & $\begin{array}{c}6.24 \\
49\end{array}$ & $\begin{array}{c}6.18 \\
49\end{array}$ & $\begin{array}{l}6.30 \\
394\end{array}$ \\
\hline Size of Classes & $\begin{array}{c}\text { mean } \\
\mathrm{n}\end{array}$ & $\begin{array}{c}5.36 \\
55\end{array}$ & $\begin{array}{c}5.83 \\
63\end{array}$ & $\begin{array}{l}5.95 \\
37\end{array}$ & $\begin{array}{c}6.00 \\
46\end{array}$ & $\begin{array}{c}6.08 \\
62\end{array}$ & $\begin{array}{c}6.06 \\
36\end{array}$ & $\begin{array}{c}6.33 \\
49\end{array}$ & $\begin{array}{c}6.10 \\
49\end{array}$ & $\begin{array}{l}5.95 \\
397\end{array}$ \\
\hline Knowledge of Professors & $\begin{array}{c}\text { mean } \\
\mathrm{n}\end{array}$ & $\begin{array}{c}5.89 \\
56\end{array}$ & $\begin{array}{c}5.94 \\
63\end{array}$ & $\begin{array}{c}6.16 \\
37\end{array}$ & $\begin{array}{c}5.76 \\
46\end{array}$ & $\begin{array}{c}5.90 \\
63\end{array}$ & $\begin{array}{c}5.78 \\
36\end{array}$ & $\begin{array}{c}5.92 \\
49\end{array}$ & $\begin{array}{c}6.16 \\
49\end{array}$ & $\begin{array}{l}5.94 \\
399\end{array}$ \\
\hline $\begin{array}{l}\text { Availability of } \\
\text { Professors }\end{array}$ & $\begin{array}{c}\text { mean } \\
\mathrm{n}\end{array}$ & $\begin{array}{c}5.81 \\
54\end{array}$ & $\begin{array}{c}5.91 \\
57\end{array}$ & $\begin{array}{c}6.00 \\
35\end{array}$ & $\begin{array}{c}5.50 \\
46\end{array}$ & $\begin{array}{c}5.92 \\
63\end{array}$ & $\begin{array}{c}5 / 67 \\
36\end{array}$ & $\begin{array}{c}5.73 \\
49\end{array}$ & $\begin{array}{c}5.73 \\
49\end{array}$ & $\begin{array}{l}5.79 \\
389\end{array}$ \\
\hline Commitment of Faculty & $\begin{array}{c}\text { mean } \\
\mathrm{n}\end{array}$ & $\begin{array}{c}5.64 \\
56\end{array}$ & $\begin{array}{l}5.77 \\
62\end{array}$ & $\begin{array}{c}6.00 \\
37 \\
\end{array}$ & $\begin{array}{c}5.57 \\
46 \\
\end{array}$ & $\begin{array}{c}5.70 \\
63 \\
\end{array}$ & $\begin{array}{c}5.53 \\
36 \\
\end{array}$ & $\begin{array}{c}5.73 \\
49 \\
\end{array}$ & $\begin{array}{c}5.82 \\
49\end{array}$ & $\begin{array}{l}5.72 \\
398 \\
\end{array}$ \\
\hline $\begin{array}{l}\text { Overall Quality of Grad } \\
\text { Business Program }\end{array}$ & $\begin{array}{c}\text { mean } \\
\mathrm{n}\end{array}$ & $\begin{array}{c}5.59 \\
56\end{array}$ & $\begin{array}{c}5.57 \\
63\end{array}$ & $\begin{array}{c}5.66 \\
38\end{array}$ & $\begin{array}{c}5.17 \\
46\end{array}$ & $\begin{array}{c}5.57 \\
63\end{array}$ & $\begin{array}{c}5.33 \\
36\end{array}$ & $\begin{array}{c}5.59 \\
49\end{array}$ & $\begin{array}{c}5.71 \\
49\end{array}$ & $\begin{array}{l}5.53 \\
400\end{array}$ \\
\hline Clarity of Course Goals & $\underset{\mathrm{n}}{\mathrm{mean}}$ & $\begin{array}{c}5.45 \\
55\end{array}$ & $\begin{array}{c}5.54 \\
63\end{array}$ & $\begin{array}{c}5.55 \\
38\end{array}$ & $\begin{array}{c}5.24 \\
46\end{array}$ & $\begin{array}{c}5.41 \\
63\end{array}$ & $\begin{array}{c}5.39 \\
36\end{array}$ & $\begin{array}{c}5.67 \\
49\end{array}$ & $\begin{array}{c}5.63 \\
49\end{array}$ & $\begin{array}{l}5.49 \\
399\end{array}$ \\
\hline Library Resources & $\underset{\mathrm{n}}{\mathrm{mean}}$ & $\begin{array}{c}5.43 \\
53\end{array}$ & $\begin{array}{c}5.50 \\
54\end{array}$ & $\begin{array}{c}5.38 \\
32\end{array}$ & $\begin{array}{c}5.29 \\
42\end{array}$ & $\begin{array}{c}5.31 \\
61\end{array}$ & $\begin{array}{c}5.31 \\
36\end{array}$ & $\begin{array}{c}5.69 \\
48\end{array}$ & $\begin{array}{c}5.75 \\
48\end{array}$ & $\begin{array}{l}5.46 \\
374\end{array}$ \\
\hline $\begin{array}{l}\text { Value of Problem- } \\
\text { Solving Assignments }\end{array}$ & $\begin{array}{c}\text { mean } \\
\mathrm{n}\end{array}$ & $\begin{array}{c}5.50 \\
56\end{array}$ & $\begin{array}{c}5.50 \\
62\end{array}$ & $\begin{array}{c}5.69 \\
39\end{array}$ & $\begin{array}{c}5.20 \\
46\end{array}$ & $\begin{array}{c}5.49 \\
63\end{array}$ & $\begin{array}{c}5.22 \\
36\end{array}$ & $\begin{array}{c}5.43 \\
49\end{array}$ & $\begin{array}{c}5.33 \\
49\end{array}$ & $\begin{array}{l}5.43 \\
400\end{array}$ \\
\hline $\begin{array}{l}\text { Value of Analytical } \\
\text { Assignments }\end{array}$ & $\underset{n}{\text { mean }}$ & $\begin{array}{c}5.45 \\
56\end{array}$ & $\begin{array}{c}5.44 \\
62\end{array}$ & $\begin{array}{c}5.72 \\
39\end{array}$ & $\begin{array}{c}5.20 \\
46\end{array}$ & $\begin{array}{c}5.40 \\
63\end{array}$ & $\begin{array}{c}5.31 \\
36\end{array}$ & $\begin{array}{c}5.43 \\
49\end{array}$ & $\begin{array}{c}5.39 \\
49\end{array}$ & $\begin{array}{l}5.41 \\
400\end{array}$ \\
\hline $\begin{array}{l}\text { Capabilities of Computer } \\
\text { Hardware }\end{array}$ & $\begin{array}{c}\text { mean } \\
\mathrm{n}\end{array}$ & $\begin{array}{c}5.31 \\
52\end{array}$ & $\begin{array}{c}5.20 \\
56\end{array}$ & $\begin{array}{c}5.33 \\
36\end{array}$ & $\begin{array}{c}5.07 \\
46\end{array}$ & $\begin{array}{c}5.39 \\
61\end{array}$ & $\begin{array}{c}5.43 \\
35\end{array}$ & $\begin{array}{c}5.69 \\
49\end{array}$ & $\begin{array}{c}5.78 \\
49\end{array}$ & $\begin{array}{l}5.40 \\
384\end{array}$ \\
\hline $\begin{array}{l}\text { Feedback From } \\
\text { Professors }\end{array}$ & $\begin{array}{c}\text { mean } \\
\mathrm{n}\end{array}$ & $\begin{array}{c}5.22 \\
55\end{array}$ & $\begin{array}{c}5.33 \\
63\end{array}$ & $\begin{array}{c}5.68 \\
38\end{array}$ & $\begin{array}{c}5.33 \\
46\end{array}$ & $\begin{array}{c}5.27 \\
63\end{array}$ & $\begin{array}{c}5.25 \\
36\end{array}$ & $\begin{array}{c}5.63 \\
49\end{array}$ & $\begin{array}{c}5.49 \\
49\end{array}$ & $\begin{array}{l}5.39 \\
399\end{array}$ \\
\hline $\begin{array}{l}\text { Access to Computers } \\
\text { (Satellite Campus) }\end{array}$ & $\underset{n}{\text { mean }}$ & $\begin{array}{c}4.86 \\
35\end{array}$ & $\begin{array}{c}5.46 \\
46\end{array}$ & $\begin{array}{l}5.67 \\
33\end{array}$ & $\begin{array}{c}4.78 \\
45\end{array}$ & $\begin{array}{c}5.20 \\
61\end{array}$ & $\begin{array}{c}5.14 \\
36\end{array}$ & $\begin{array}{c}5.76 \\
49\end{array}$ & $\begin{array}{c}5.69 \\
48\end{array}$ & $\begin{array}{l}5.33 \\
353\end{array}$ \\
\hline Computer Software & mean & $\begin{array}{c}5.45 \\
49\end{array}$ & $\begin{array}{c}5.06 \\
52\end{array}$ & $\begin{array}{c}5.61 \\
33\end{array}$ & $\begin{array}{c}5.02 \\
46\end{array}$ & $\begin{array}{c}5.02 \\
61\end{array}$ & $\begin{array}{c}5.08 \\
36\end{array}$ & $\begin{array}{c}5 / 67 \\
49\end{array}$ & $\begin{array}{c}5.71 \\
48\end{array}$ & $\begin{array}{l}5.31 \\
374\end{array}$ \\
\hline Presentation of Material & $\underset{\mathrm{n}}{\mathrm{mean}}$ & $\begin{array}{c}5.32 \\
56\end{array}$ & $\begin{array}{c}5.37 \\
63\end{array}$ & $\begin{array}{c}5.54 \\
39\end{array}$ & $\begin{array}{c}5.22 \\
46\end{array}$ & $\begin{array}{c}5.17 \\
63\end{array}$ & $\begin{array}{c}5.11 \\
36\end{array}$ & $\begin{array}{c}5.31 \\
49\end{array}$ & $\begin{array}{c}5.29 \\
49\end{array}$ & $\begin{array}{l}5.29 \\
401\end{array}$ \\
\hline Relevance of Material & $\begin{array}{c}\text { mean } \\
\mathrm{n}\end{array}$ & $\begin{array}{c}5.41 \\
36\end{array}$ & $\begin{array}{c}5.16 \\
63\end{array}$ & $\begin{array}{c}5.31 \\
39\end{array}$ & $\begin{array}{c}5.07 \\
46\end{array}$ & $\begin{array}{c}5.16 \\
63\end{array}$ & $\begin{array}{c}5.17 \\
36\end{array}$ & $\begin{array}{c}5.35 \\
49\end{array}$ & $\begin{array}{c}5.45 \\
49\end{array}$ & $\begin{array}{l}5.26 \\
401\end{array}$ \\
\hline Library Hours & $\begin{array}{c}\text { mean } \\
n\end{array}$ & $\begin{array}{c}4.84 \\
51\end{array}$ & $\begin{array}{c}5.43 \\
54\end{array}$ & $\begin{array}{c}5.58 \\
33\end{array}$ & $\begin{array}{c}5.05 \\
42\end{array}$ & $\begin{array}{c}5.48 \\
61\end{array}$ & $\begin{array}{c}4.81 \\
36\end{array}$ & $\begin{array}{c}5.31 \\
48\end{array}$ & $\begin{array}{c}5.53 \\
49\end{array}$ & $\begin{array}{l}5.26 \\
374\end{array}$ \\
\hline $\begin{array}{l}\text { Value of Group Project } \\
\text { Assignments }\end{array}$ & $\begin{array}{c}\text { mean } \\
\mathrm{n}\end{array}$ & $\begin{array}{c}5.50 \\
56\end{array}$ & $\begin{array}{c}5.74 \\
62\end{array}$ & $\begin{array}{c}5.18 \\
38\end{array}$ & $\begin{array}{c}4.91 \\
46\end{array}$ & $\begin{array}{c}5.10 \\
63\end{array}$ & $\begin{array}{c}4.92 \\
36\end{array}$ & $\begin{array}{c}5.24 \\
49\end{array}$ & $\begin{array}{c}5.04 \\
49\end{array}$ & $\begin{array}{l}5.24 \\
399\end{array}$ \\
\hline $\begin{array}{l}\text { Value of Writing } \\
\text { Assignments }\end{array}$ & $\begin{array}{c}\text { mean } \\
\mathrm{n}\end{array}$ & $\begin{array}{c}5.29 \\
56\end{array}$ & $\begin{array}{c}5.48 \\
62\end{array}$ & $\begin{array}{c}5.28 \\
39\end{array}$ & $\begin{array}{c}4.67 \\
46\end{array}$ & $\begin{array}{c}5.11 \\
63\end{array}$ & $\begin{array}{c}4.89 \\
36\end{array}$ & $\begin{array}{c}5.24 \\
49\end{array}$ & $\begin{array}{c}5.08 \\
49\end{array}$ & $\begin{array}{l}5.15 \\
400\end{array}$ \\
\hline
\end{tabular}




\begin{tabular}{|c|c|c|c|c|c|c|c|c|c|c|}
\hline Integration of Material & mean & 5.13 & 4.98 & 5.26 & 4.98 & 4.79 & 4.86 & 5.24 & 5.37 & 5.07 \\
\hline Between Courses & $\mathrm{n}$ & 54 & 62 & 38 & 46 & 63 & 36 & 49 & 49 & 397 \\
\hline \multirow{2}{*}{ Scheduling of Courses } & mean & 4.70 & 4.76 & 4.79 & 4.65 & 5.14 & 4.86 & 5.37 & 5.31 & 4.95 \\
\hline & $\mathrm{n}$ & 54 & 63 & 39 & 36 & 63 & 36 & 49 & 49 & 399 \\
\hline \multirow{2}{*}{$\begin{array}{l}\text { Access to Computers } \\
\text { (Main Campus) }\end{array}$} & mean & 4.11 & 4.30 & 4.39 & 4.34 & 5.16 & 4.94 & 5.63 & 5.46 & 4.83 \\
\hline & $\mathrm{n}$ & 47 & 46 & 28 & 44 & 61 & 36 & 48 & 48 & 358 \\
\hline \multirow[t]{2}{*}{ Availability of Electives } & mean & 4.37 & 4.38 & 4.39 & 4.04 & 4.67 & 4.03 & 4.65 & 5.00 & 4.46 \\
\hline & $\mathrm{n}$ & 56 & 61 & 38 & 46 & 63 & 36 & 49 & 49 & 398 \\
\hline \multirow{2}{*}{$\begin{array}{l}\text { Classroom Facilities } \\
\text { (Main Campus) }\end{array}$} & mean & 3.88 & 3.63 & 3.77 & 3.57 & 4.46 & 4.33 & 4.94 & 4.96 & 4.19 \\
\hline & $\mathrm{n}$ & 56 & 63 & 39 & 46 & 63 & 36 & 49 & 49 & 401 \\
\hline
\end{tabular}

\section{MBA Alumni Cite Reasons For Recommending Our Program}

As described earlier, we survey our MBA alumni four years after graduation. Thus, we have no alumni survey results for years beyond the class of 2000, and have therefore decided to present results for the classes that graduated between 1995 and 2000. There were 167 alumni respondents over that time period, and 92.7 percent signified that they would recommend our program. There were 152 respondents who listed up to three reasons they would recommend our MBA Program. Their responses are summarized in Table 4.

Table 4

Summary Of Reasons For Recommending Program: Classes Of 1995 - 2000

\begin{tabular}{|l|c|c|}
\hline Reason For Recommending Program & Frequency & $\begin{array}{c}\text { Percent of Respondents Who Listed This Reason For } \\
\text { Recommending Our Program }\end{array}$ \\
\hline Faculty Competence & 53 & $34.9 \%$ \\
\hline Small Class Size & 43 & $28.3 \%$ \\
\hline Quality Of Program & 35 & $23.0 \%$ \\
\hline Program Reputation & 34 & $22.4 \%$ \\
\hline Flexibility In Scheduling & 26 & $17.1 \%$ \\
\hline Personal Attention & 25 & $16.4 \%$ \\
\hline Accommodate Working Student & 17 & $11.2 \%$ \\
\hline Faculty With Real World Experience & 12 & $7.9 \%$ \\
\hline General Location & 12 & $7.9 \%$ \\
\hline AACSB Accreditation & 9 & $5.9 \%$ \\
\hline Networking/Ties To Business Community & 9 & $5.9 \%$ \\
\hline Variety Of Courses/Electives & 9 & $5.9 \%$ \\
\hline
\end{tabular}

Responses in Table 4 were given to open-end questions on the survey. So of the $152 \mathrm{MBA}$ alumni who would recommend the program, 53 or 34.9 percent named Faculty Competence as one of up to three important factors that motivated them to recommend our MBA Program. The top four reasons in Table 4 form the most dominant grouping with response rates between 34.9 percent for Faculty Competence and 22.4 percent for Program Reputation. Three of these four - Faculty Competence, Quality of Program, and Program Reputation - all relate to perceived quality of our program. We are pleased that our alumni both recognized and assigned high value to the quality dimensions of our Graduate Business Programs. This clearly suggests that the program delivers on its promises. For the most part these results comport well with results in Table 2 wherein new matriculates identified "quality dimensions" as primary attributes motivating their choice of Graduate Business Program. It is curious to note the decline in the relative importance of AACSB Accreditation. While the students considered it very important when they selected the program, they do not consider it an important reason for recommending the program. This suggests that as the students become more familiar with the program they rely less heavily on proxy quality measures such as AACSB Accreditation. 


\section{Survey Items Concerned With Critical Skills}

The central focus of this work will be directed towards an examination of ratings of the importance of nine skills deemed to be critical by the host institution. Identification of these skills was motivated in great part by language in the AACSB Standards for Business Accreditation. The skills are listed below in the order that they appear on the survey.

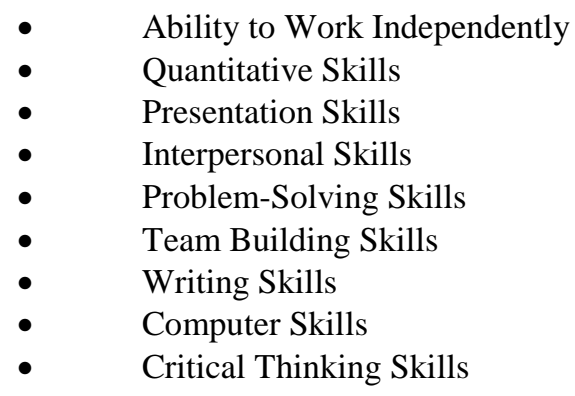
on the surveys.

With respect to the above skills and graduate student respondent groups, the following issues were addressed

\section{New MBA Matriculates}

Newly matriculating MBA students were asked: "Concerning your professional goals and expectations with respect to your Graduate Business Programs studies: How important is it to develop your skills in the following areas?" The nine skills were then rated on a scale of 1 (Not Important) to 7 (Very Important). Additionally, each student was asked to identify the first and second Most Important Skills.

\section{Recent MBA Graduates}

Recent graduates were asked a slightly different question: "Concerning your professional goals and expectations with respect to your Graduate Business Programs studies: How successful was your program of study in the development of your skills in the following areas?" The nine skills were rated on a scale from 1 (Not Successful) to 7 (Very Successful). Additionally, each respondent was asked to identify the first and second Most Important Skills.

\section{MBA Alumni}

MBA alumni were asked to give up to three responses to each of the following two items.

- $\quad$ "Which skills (if any) were MOST IMPROVED?" (i.e., 1st, 2nd, and 3rd most improved).

- "Which skills are MOST IMPORTANT TO YOUR PROFESSIONAL GOALS AND DEVELOPMENT?" (i.e., 1st, 2nd, and 3rd most important).

\section{Results Concerning Ratings Of The Nine Critical Skills}

Once again, the primary goal of this research is to evaluate respondent opinions with respect to the nine skills that we have identified as being critical to graduate business education. Comparative results of assessments among the three graduate student groups (new MBA matriculates, recent MBA graduates, and MBA alumni) will be presented and contrasted. 
New Matriculates: Importance Of Specific Skills

The nine skills areas and results are summarized in Table 5 where the skills are listed in descending order according to total average response over the eight-year time horizon from 1997-2004. There are clearly three distinct tiers represented with respect to the skills deemed to be most important by our newly matriculating MBA respondents.

- $\quad$ Tier 1: Critical Thinking earned an average total rating of 6.13 making this skill the highest rated on the scale of importance according to our newly matriculating MBA students. It is noteworthy that Critical Thinking also had the smallest standard deviation (1.04), signifying that students were consistent in their high rating of the importance of Critical Thinking. Problem-solving followed closely with a total average response of 6.00, and earned the only other spot on tier 1 .

- $\quad$ Tier 2: Four skills were identified as very important, and occupy the second tier of Table 2. These skills and their average ratings over the eight year period are: Presentation (5.73), Team Building (5.67), Interpersonal (5.61), and Quantitative (5.60).

- $\quad$ Tier 3: Tier 3 is represented by the following three skills: Writing (5.35), Computer (5.24), and Work Independently (5.17). Perhaps most importantly, the lowest average total rating in Table 5 is the 5.17 for Work Independently, and this is still on the high or important end of the seven-point scale.

Table 5

New Matriculates: Ratings Of Importance Of Specific Skills [1=Not Important ... 7=Very Important]

\begin{tabular}{|c|c|c|c|c|c|c|c|c|c|c|}
\hline Skill & & 1997 & 1998 & 1999 & 2000 & 2001 & 2002 & 2003 & 2004 & Totals \\
\hline $\begin{array}{l}\text { Critical } \\
\text { Thinking }\end{array}$ & $\begin{array}{c}\text { mean } \\
\mathrm{n} \\
\mathrm{s} \\
\mathrm{MI} \%\end{array}$ & $\begin{array}{c}6.23 \\
62 \\
1.03 \\
29.0 \%\end{array}$ & $\begin{array}{c}6.26 \\
38 \\
0.95 \\
10.8 \%\end{array}$ & $\begin{array}{c}6.24 \\
45 \\
1.11 \\
15.6 \%\end{array}$ & $\begin{array}{c}6.07 \\
41 \\
0.91 \\
16.7 \%\end{array}$ & $\begin{array}{c}6.34 \\
62 \\
0.87 \\
29.0 \%\end{array}$ & $\begin{array}{c}6.00 \\
63 \\
1.19 \\
22.2 \%\end{array}$ & $\begin{array}{c}6.09 \\
67 \\
1.08 \\
18.5 \%\end{array}$ & $\begin{array}{c}5.84 \\
50 \\
1.02 \\
14.6 \%\end{array}$ & $\begin{array}{c}6.13 \\
428 \\
1.04 \\
20.5 \%\end{array}$ \\
\hline $\begin{array}{l}\text { Problem- } \\
\text { solving }\end{array}$ & $\begin{array}{c}\text { mean } \\
\mathrm{n} \\
\mathrm{s} \\
\mathrm{MI} \%\end{array}$ & $\begin{array}{c}6.00 \\
62 \\
1.17 \\
19.4 \%\end{array}$ & $\begin{array}{c}6.05 \\
38 \\
1.18 \\
21.6 \%\end{array}$ & $\begin{array}{c}6.27 \\
45 \\
1.12 \\
15.6 \%\end{array}$ & $\begin{array}{c}6.02 \\
42 \\
1.28 \\
28.6 \%\end{array}$ & $\begin{array}{c}6.10 \\
61 \\
1.12 \\
17.7 \%\end{array}$ & $\begin{array}{c}5.75 \\
63 \\
1.27 \\
7.9 \%\end{array}$ & $\begin{array}{c}5.88 \\
67 \\
1.14 \\
18.5 \%\end{array}$ & $\begin{array}{c}6.02 \\
50 \\
0.98 \\
18.8 \%\end{array}$ & $\begin{array}{c}6.00 \\
428 \\
1.16 \\
17.9 \%\end{array}$ \\
\hline Presentation & $\begin{array}{c}\text { mean } \\
\mathrm{n} \\
\mathrm{s} \\
\mathrm{MI} \%\end{array}$ & $\begin{array}{c}5.63 \\
63 \\
1.45 \\
8.1 \%\end{array}$ & $\begin{array}{c}5.87 \\
38 \\
1.12 \\
2.7 \%\end{array}$ & $\begin{array}{c}5.86 \\
44 \\
1.09 \\
6.7 \%\end{array}$ & $\begin{array}{c}5.71 \\
42 \\
1.22 \\
11.9 \%\end{array}$ & $\begin{array}{c}5.77 \\
62 \\
1.22 \\
9.7 \%\end{array}$ & $\begin{array}{c}5.84 \\
63 \\
1.10 \\
19.0 \%\end{array}$ & $\begin{array}{c}5.73 \\
67 \\
1.14 \\
15.4 \%\end{array}$ & $\begin{array}{c}5.46 \\
50 \\
1.43 \\
18.8 \%\end{array}$ & $\begin{array}{c}5.73 \\
429 \\
1.23 \\
12.0 \%\end{array}$ \\
\hline $\begin{array}{l}\text { Team } \\
\text { Building }\end{array}$ & $\begin{array}{c}\text { mean } \\
\mathrm{n} \\
\mathrm{s} \\
\mathrm{MI} \%\end{array}$ & $\begin{array}{c}5.39 \\
62 \\
1.50 \\
8.1 \%\end{array}$ & $\begin{array}{c}5.97 \\
38 \\
0.94 \\
13.5 \%\end{array}$ & $\begin{array}{c}5.84 \\
45 \\
1.17 \\
8.9 \%\end{array}$ & $\begin{array}{c}5.57 \\
42 \\
1.13 \\
4.8 \%\end{array}$ & $\begin{array}{c}5.79 \\
61 \\
1.13 \\
11.3 \%\end{array}$ & $\begin{array}{c}5.75 \\
63 \\
1.28 \\
6.3 \%\end{array}$ & $\begin{array}{c}5.51 \\
67 \\
1.26 \\
10.8 \%\end{array}$ & $\begin{array}{c}5.66 \\
50 \\
1.10 \\
10.4 \%\end{array}$ & $\begin{array}{c}5.67 \\
428 \\
1.22 \\
9.2 \%\end{array}$ \\
\hline Interpersonal & $\begin{array}{c}\text { mean } \\
\mathrm{n} \\
\mathrm{s} \\
\mathrm{MI} \%\end{array}$ & $\begin{array}{c}5.39 \\
62 \\
1.72 \\
12.9 \%\end{array}$ & $\begin{array}{c}5.95 \\
38 \\
0.96 \\
18.9 \%\end{array}$ & $\begin{array}{c}5.82 \\
45 \\
1.28 \\
17.8 \%\end{array}$ & $\begin{array}{c}5.43 \\
42 \\
1.15 \\
11.9 \%\end{array}$ & $\begin{array}{c}5.69 \\
62 \\
1.29 \\
12.9 \%\end{array}$ & $\begin{array}{c}5.73 \\
63 \\
1.23 \\
12.7 \%\end{array}$ & $\begin{array}{c}5.55 \\
67 \\
1.43 \\
13.8 \%\end{array}$ & $\begin{array}{c}5.44 \\
50 \\
1.23 \\
10.4 \%\end{array}$ & $\begin{array}{c}5.61 \\
429 \\
1.33 \\
13.7 \%\end{array}$ \\
\hline Quantitative & $\begin{array}{c}\text { mean } \\
\mathrm{n} \\
\mathrm{s} \\
\mathrm{MI} \%\end{array}$ & $\begin{array}{c}5.41 \\
63 \\
1.43 \\
8.1 \%\end{array}$ & $\begin{array}{c}5.63 \\
38 \\
1.24 \\
16.2 \%\end{array}$ & $\begin{array}{c}5.64 \\
45 \\
1.40 \\
13.3 \%\end{array}$ & $\begin{array}{c}5.74 \\
42 \\
1.13 \\
11.9 \%\end{array}$ & $\begin{array}{c}5.68 \\
62 \\
1.28 \\
9.7 \%\end{array}$ & $\begin{array}{c}5.63 \\
63 \\
1.08 \\
17.5 \%\end{array}$ & $\begin{array}{c}5.58 \\
67 \\
1.21 \\
9.2 \%\end{array}$ & $\begin{array}{c}5.52 \\
50 \\
1.13 \\
10.4 \%\end{array}$ & $\begin{array}{c}5.60 \\
430 \\
1.24 \\
11.8 \%\end{array}$ \\
\hline Writing & $\begin{array}{c}\text { mean } \\
\mathrm{n} \\
\mathrm{s} \\
\mathrm{MI} \%\end{array}$ & $\begin{array}{c}5.37 \\
63 \\
1.42 \\
6.5 \%\end{array}$ & $\begin{array}{c}5.13 \\
38 \\
1.36 \\
5.4 \%\end{array}$ & $\begin{array}{c}5.67 \\
45 \\
1.15 \\
4.4 \%\end{array}$ & $\begin{array}{c}5.44 \\
41 \\
1.32 \\
4.8 \%\end{array}$ & $\begin{array}{c}5.42 \\
62 \\
1.47 \\
3.2 \%\end{array}$ & $\begin{array}{c}5.27 \\
63 \\
1.42 \\
1.6 \%\end{array}$ & $\begin{array}{c}5.48 \\
67 \\
1.30 \\
6.2 \%\end{array}$ & $\begin{array}{c}5.00 \\
50 \\
1.63 \\
6.3 \%\end{array}$ & $\begin{array}{c}5.35 \\
429 \\
1.39 \\
4.7 \%\end{array}$ \\
\hline Computer & $\begin{array}{c}\text { mean } \\
\mathrm{n} \\
\mathrm{s} \\
\mathrm{MI} \%\end{array}$ & $\begin{array}{c}5.29 \\
62 \\
1.58 \\
4.8 \%\end{array}$ & $\begin{array}{c}5.21 \\
38 \\
1.82 \\
5.4 \%\end{array}$ & $\begin{array}{c}5.36 \\
45 \\
1.75 \\
8.9 \%\end{array}$ & $\begin{array}{c}5.20 \\
41 \\
1.72 \\
4.8 \%\end{array}$ & $\begin{array}{c}5.23 \\
62 \\
1.66 \\
1.6 \%\end{array}$ & $\begin{array}{c}5.22 \\
63 \\
1.55 \\
3.2 \%\end{array}$ & $\begin{array}{c}5.36 \\
67 \\
1.48 \\
3.1 \%\end{array}$ & $\begin{array}{c}5.00 \\
50 \\
1.57 \\
6.3 \%\end{array}$ & $\begin{array}{c}5.24 \\
428 \\
1.62 \\
4.5 \%\end{array}$ \\
\hline
\end{tabular}




\begin{tabular}{|l|c|c|c|c|c|c|c|c|c|c|}
\hline Work & mean & 4.74 & 5.43 & 5.64 & 4.95 & 5.23 & 5.48 & 5.22 & 4.70 & 5.17 \\
Independently & $\mathrm{n}$ & 62 & 37 & 45 & 42 & 62 & 63 & 67 & 50 & 428 \\
& $\mathrm{~s}$ & 1.89 & 1.61 & 1.43 & 1.48 & 1.68 & 1.28 & 1.70 & 1.63 & 1.63 \\
& $\mathrm{MI} \%$ & $3.2 \%$ & $5.4 \%$ & $8.9 \%$ & $4.8 \%$ & $4.8 \%$ & $9.5 \%$ & $4.6 \%$ & $4.2 \%$ & $5.7 \%$ \\
\hline
\end{tabular}

$*$ MI $\%=$ Percent of respondents who identified this attribute as being the Most Important

\section{Recent MBA Graduates: Success of Development of Specific Skills}

Our recent graduates are an invaluable source of information with respect to how successful we were in the presentation and development of the nine critical skills. Table 6 divulges that the most successfully developed skills were Critical Thinking, Problem-solving, and Work Independently, followed closely by Quantitative and Team Building skills. This is good news since new matriculates indicated that Critical Thinking and Problem-solving were clearly the most important skills (see Table 5). The two lowest rated skills in Table 6 are Writing and Computer skills. Both are consistently lower than the other skills over the eight year time horizon. At departmental and curriculum committee meetings, faculty should investigate and discuss the presentation of material related to these (and other) skills. A caveat is in order though. Prior to our MBA Program, the skill may already have been strong or well developed. For example, many of our MBA students come to the program with superior computer skills. When asked to rate the success of skills development, perhaps even a marginally developed new skill would score higher than the previously developed strong computer skills.

Table 6

Graduating Mbas: Ratings Of Success Concerning Development Of Specific Skills [1=Not Successful ... 7=Very Successful]

\begin{tabular}{|c|c|c|c|c|c|c|c|c|c|c|}
\hline Skill & & 1997 & 1998 & 1999 & 2000 & 2001 & 2002 & 2003 & 2004 & Totals \\
\hline Critical & mean & 5.57 & 5.52 & 5.56 & 5.46 & 5.76 & 5.44 & 5.59 & 5.80 & 5.60 \\
\hline \multirow[t]{3}{*}{ Thinking } & $\mathrm{n}$ & 56 & 63 & 39 & 46 & 63 & 36 & 49 & 49 & 401 \\
\hline & $\mathrm{s}$ & 1.16 & 1.06 & 1.07 & 1.13 & 1.07 & 0.88 & 1.00 & 0.89 & 1.04 \\
\hline & MI \% & $23.2 \%$ & $33.3 \%$ & $23.1 \%$ & $30.4 \%$ & $44.4 \%$ & $19.4 \%$ & $32.7 \%$ & $26.5 \%$ & $30.2 \%$ \\
\hline \multirow{4}{*}{$\begin{array}{l}\text { Problem- } \\
\text { solving }\end{array}$} & mean & 5.57 & 5.52 & 5.64 & 5.33 & 5.59 & 5.36 & 5.37 & 5.53 & 5.50 \\
\hline & $\mathrm{n}$ & 56 & 63 & 39 & 46 & 63 & 36 & 49 & 49 & 401 \\
\hline & $\mathrm{s}$ & 1.09 & 0.98 & 1.06 & 1.03 & 1.12 & 0.72 & 1.01 & 0.84 & 1.00 \\
\hline & MI \% & $32.1 \%$ & $31.7 \%$ & $28.2 \%$ & $34.8 \%$ & $22.2 \%$ & $38.9 \%$ & $18.4 \%$ & $30.6 \%$ & $29.2 \%$ \\
\hline \multirow{4}{*}{$\begin{array}{l}\text { Work } \\
\text { Independently }\end{array}$} & mean & 5.62 & 5.50 & 5.59 & 5.22 & 5.41 & 5.42 & 5.60 & 5.65 & 5.50 \\
\hline & $\mathrm{n}$ & 56 & 62 & 39 & 46 & 63 & 36 & 48 & 49 & 399 \\
\hline & $\mathrm{s}$ & 1.02 & 1.08 & 0.91 & 1.09 & 1.16 & 0.97 & 1.07 & 1.01 & 1.05 \\
\hline & MI \% & $7.1 \%$ & $1.6 \%$ & $7.7 \%$ & $4.3 \%$ & $3.2 \%$ & $0.0 \%$ & $6.1 \%$ & $0.0 \%$ & $3.7 \%$ \\
\hline \multirow[t]{4}{*}{ Quantitative } & mean & 5.16 & 5.37 & 5.59 & 5.35 & 5.44 & 5.08 & 5.51 & 5.53 & 5.38 \\
\hline & $\mathrm{n}$ & 56 & 62 & 39 & 46 & 63 & 36 & 49 & 49 & 400 \\
\hline & $\mathrm{s}$ & 1.04 & 1.00 & 1.02 & 1.20 & 1.09 & 1.03 & 1.23 & 0.79 & 1.06 \\
\hline & MI \% & $7.1 \%$ & $4.8 \%$ & $20.5 \%$ & $10.9 \%$ & $3.2 \%$ & $8.3 \%$ & $10.2 \%$ & $0.0 \%$ & $7.5 \%$ \\
\hline Team & mean & 5.57 & 5.52 & 5.26 & 5.09 & 5.31 & 5.00 & 5.37 & 5.27 & 5.32 \\
\hline \multirow[t]{3}{*}{ Building } & $\mathrm{n}$ & 56 & 63 & 39 & 46 & 62 & 36 & 49 & 49 & 400 \\
\hline & $\mathrm{s}$ & 1.13 & 1.38 & 1.16 & 1.30 & 1.34 & 1.33 & 1.09 & 1.17 & 1.25 \\
\hline & MI \% & $14.3 \%$ & $11.1 \%$ & $0.0 \%$ & $2.2 \%$ & $7.9 \%$ & $11.1 \%$ & $6.1 \%$ & $14.3 \%$ & $8.7 \%$ \\
\hline \multirow[t]{4}{*}{ Presentation } & mean & 5.30 & 5.27 & 5.33 & 5.00 & 5.30 & 4.94 & 5.45 & 5.22 & 5.24 \\
\hline & $\mathrm{n}$ & 56 & 63 & 39 & 46 & 63 & 36 & 49 & 49 & 4.01 \\
\hline & $\mathrm{s}$ & 1.06 & 1.36 & 1.22 & 1.27 & 1.28 & 1.45 & 1.21 & 1.14 & 1.25 \\
\hline & MI \% & $3.6 \%$ & $1.6 \%$ & $5.1 \%$ & $6.5 \%$ & $6.3 \%$ & $5.6 \%$ & $8.2 \%$ & $6.1 \%$ & $5.2 \%$ \\
\hline \multirow[t]{4}{*}{ Interpersonal } & mean & 5.26 & 5.26 & 5.23 & 5.04 & 5.21 & 4.92 & 5.24 & 5.35 & 5.20 \\
\hline & $\mathrm{n}$ & 54 & 61 & 39 & 46 & 63 & 36 & 49 & 48 & 396 \\
\hline & $\mathrm{s}$ & 1.20 & 1.33 & 1.11 & 1.10 & 1.21 & 1.20 & 1.09 & 1.10 & 1.17 \\
\hline & MI \% & $8.9 \%$ & $11.1 \%$ & $12.8 \%$ & $4.3 \%$ & $3.2 \%$ & $16.7 \%$ & $10.2 \%$ & $10.2 \%$ & $9.2 \%$ \\
\hline \multirow[t]{4}{*}{ Writing } & mean & 5.11 & 5.37 & 4.90 & 4.96 & 5.05 & 4.72 & 4.96 & 4.80 & 5.01 \\
\hline & $\mathrm{n}$ & 56 & 63 & 39 & 46 & 63 & 36 & 49 & 49 & 401 \\
\hline & $\mathrm{s}$ & 1.09 & 1.22 & 1.27 & 1.38 & 1.26 & 1.16 & 1.12 & 1.24 & 1.23 \\
\hline & MI \% & $1.8 \%$ & $4.8 \%$ & $2.6 \%$ & $2.2 \%$ & $4.8 \%$ & $0.0 \%$ & $2.0 \%$ & $8.2 \%$ & $3.5 \%$ \\
\hline
\end{tabular}




\begin{tabular}{|l|c|c|c|c|c|c|c|c|c|c|}
\hline Computer & mean & 4.84 & 5.08 & 5.08 & 4.76 & 5.11 & 4.22 & 5.04 & 4.69 & 4.89 \\
& $\mathrm{n}$ & 56 & 63 & 39 & 46 & 63 & 36 & 49 & 49 & 401 \\
& $\mathrm{~s}$ & 1.46 & 1.53 & 1.55 & 1.42 & 1.30 & 1.55 & 1.26 & 1.31 & 1.43 \\
& $\mathrm{MI} \%$ & $1.8 \%$ & $0.0 \%$ & $0.0 \%$ & $4.3 \%$ & $4.8 \%$ & $0.0 \%$ & $6.1 \%$ & $4.1 \%$ & $2.7 \%$ \\
\hline
\end{tabular}

$*$ MI $\%=$ Percent of respondents who identified this attribute as being the Most Important

\section{MBA Alumni: Most Improved Skills}

We were eager to learn which skills were most improved, and which were most important in the opinions of our MBA alumni. On the alumni surveys, the skills were not rated on a seven-point scale. Rather, MBA alumni were afforded the opportunity to list up to three responses for each of the following items:

- "Which skills (if any) were MOST IMPROVED?"

- "Which skills do you feel are MOST IMPORTANT TO YOUR PROFESSIONAL GOALS AND DEVELOPMENT?"

The reader should note that 2 nd and 3 rd mentions are not included in Tables 7 and 8 . Thus, Table 7 depicts results for the most improved skill. For example, in 1995, 5 of 23 alumni respondents (21.7 percent) named Quantitative as the most improved skill. The reader is reminded that alumni were surveyed four years after graduation, and that the class of 2000 is our most recent alumni data. It is interesting to note that, on the basis of total mentions, Quantitative edged out Critical Thinking as the most improved skill. The bottom four skills listed in Table 7, Computer, Interpersonal, Work Independently, and Writing received few mentions as most improved.

Table 7

MBA Alumni: Listings Of Most Improved Skill

\begin{tabular}{|l|c|c|c|c|c|c|c|c|}
\hline Skill & & $\mathbf{1 9 9 5}$ & $\mathbf{1 9 9 6}$ & $\mathbf{1 9 9 7}$ & $\mathbf{1 9 9 8}$ & $\mathbf{1 9 9 9}$ & $\mathbf{2 0 0 0}$ & Totals \\
\hline Quantitative & $\mathrm{n}$ & 5 & 9 & 5 & 8 & 7 & 3 & 37 \\
& $\%$ & 21.7 & 29.0 & 18.5 & 23.5 & 22.6 & 15.8 & \\
\cline { 1 - 8 } Critical Thinking & $\mathrm{n}$ & 3 & 6 & 8 & 6 & 7 & 6 & 22.4 \\
\cline { 1 - 8 } & $\%$ & 13.0 & 19.4 & 29.6 & 17.6 & 22.6 & 31.6 & 21.8 \\
\hline Problem-Solving & $\mathrm{n}$ & 2 & 4 & 7 & 8 & 5 & 3 & 29 \\
& $\%$ & 8.7 & 12.9 & 25.9 & 23.5 & 16.1 & 15.8 & 17.6 \\
\hline Team Building & $\mathrm{n}$ & 4 & 4 & 4 & 5 & 5 & 4 & 26 \\
& $\%$ & 17.4 & 12.9 & 14.8 & 14.7 & 16.1 & 21.1 & 15.8 \\
\hline Presentation & $\mathrm{n}$ & 6 & 4 & 2 & 1 & 1 & 1 & 15 \\
& $\%$ & 26.1 & 12.9 & 7.4 & 2.9 & 3.2 & 5.3 & 9.1 \\
\hline Computer & $\mathrm{n}$ & 1 & 2 & 0 & 2 & 3 & 0 & 8 \\
& $\%$ & 4.3 & 6.5 & 0.0 & 5.9 & 9.7 & 0.0 & 4.8 \\
\hline Interpersonal & $\mathrm{n}$ & 1 & 2 & 1 & 1 & 1 & 1 & 7 \\
& $\%$ & 4.3 & 6.5 & 3.7 & 2.9 & 3.2 & 5.3 & 4.2 \\
\hline Work Independently & $\mathrm{n}$ & 0 & 0 & 0 & 2 & 1 & 1 & 4 \\
& $\%$ & 0.0 & 0.0 & 0.0 & 5.9 & 3.2 & 5.3 & 2.4 \\
\hline Writing & $\mathrm{n}$ & 1 & 0 & 0 & 1 & 1 & 0 & 3 \\
& $\%$ & 4.3 & 0.0 & 0.0 & 2.9 & 3.2 & 0.0 & 1.8 \\
\hline Totals & $\mathrm{n}$ & 23 & 31 & 27 & 34 & 31 & 19 & 165 \\
& $\%$ & 100.0 & 100.0 & 100.0 & 100.0 & 100.0 & 100.0 & 100.0 \\
\hline
\end{tabular}


Table 8

MBA Alumni: Listings Of Most Important Skills

\begin{tabular}{|l|c|c|c|c|c|c|c|c|c|}
\hline Skill & & $\mathbf{1 9 9 5}$ & $\mathbf{1 9 9 6}$ & $\mathbf{1 9 9 7}$ & $\mathbf{1 9 9 8}$ & $\mathbf{1 9 9 9}$ & $\mathbf{2 0 0 0}$ & Totals \\
\hline Critical Thinking & $\mathrm{n}$ & 3 & 6 & 11 & 12 & 9 & 3 & 44 \\
& $\%$ & 13.6 & 19.4 & 40.7 & 34.3 & 29.0 & 15.8 & 26.7 \\
\hline Problem-Solving & $\mathrm{n}$ & 1 & 5 & 8 & 9 & 9 & 6 & 38 \\
& $\%$ & 4.5 & 16.1 & 29.6 & 25.7 & 29.0 & 31.6 & 23.0 \\
\hline Presentation & $\mathrm{n}$ & 9 & 7 & 1 & 4 & 0 & 2 & 23 \\
& $\%$ & 40.9 & 22.6 & 3.7 & 11.4 & 0.0 & 10.5 & 13.9 \\
\hline Team Building & $\mathrm{n}$ & 4 & 3 & 3 & 4 & 1 & 1 & 16 \\
& $\%$ & 18.2 & 9.7 & 11.1 & 11.4 & 3.2 & 5.3 & 9.7 \\
\hline Interpersonal & $\mathrm{n}$ & 1 & 4 & 1 & 3 & 5 & 2 & 16 \\
& $\%$ & 4.5 & 12.9 & 3.7 & 8.6 & 16.1 & 10.5 & 9.7 \\
\hline Quantitative & $\mathrm{n}$ & 2 & 2 & 2 & 1 & 2 & 2 & 1 \\
& $\%$ & 9.1 & 6.5 & 7.4 & 2.9 & 6.5 & 10.5 & 6.7 \\
\hline Computer & $\mathrm{n}$ & 0 & 2 & 0 & 1 & 4 & 1 & 8 \\
& $\%$ & 0.0 & 6.5 & 0.0 & 2.9 & 12.9 & 5.3 & 4.8 \\
\hline Work Independently & $\mathrm{n}$ & 1 & 1 & 1 & 0 & 1 & 2 & 6 \\
& $\%$ & 4.5 & 3.2 & 3.7 & 0.0 & 3.2 & 10.5 & 3.6 \\
\hline Writing & $\mathrm{n}$ & 1 & 1 & 0 & 1 & 0 & 0 & 3 \\
& $\%$ & 4.5 & 3.2 & 0.0 & 2.9 & 0.0 & 0.0 & 1.8 \\
\hline Totals & $\mathrm{n}$ & 22 & 31 & 27 & 35 & 31 & 19 & 165 \\
& $\%$ & 100.0 & 100.0 & 100.0 & 100.0 & 100.0 & 100.0 & \\
\hline
\end{tabular}

\section{MBA Alumni: Most Important Skills}

As shown in Table 8, MBA alumni expressed significant support for two skills as being most important: 26.7 percent identified Critical Thinking and 23.0 percent identified Problem-Solving as most important. There was consistent agreement among the ratings of importance of these skills by our new matriculates (Table 5), our graduating MBAs (Table 6), and our MBA alumni (Table 8). The three-tiered structure on the basis of total average ratings in Table 5 is affirmed and very evident on the basis of mentions as the most important skill in Tables 5, 6 and 8. The precise ordering of the nine skills is slightly different in these tables, but the three tiers clearly evident are:

- $\quad$ Tier 1: Critical Thinking and Problem-Solving;

- $\quad$ Tier 2: Presentation, Team Building, Interpersonal, and Quantitative;

- $\quad$ Tier 3: Computer, Work Independently, and Writing.

New Matriculates, Graduating MBAs, and Alumni: Comparative Rankings of The Most Important Skill

Analysis of the percents of respondents who named each skill as being the most important is warranted.

Table 9 is a table of rankings, and presents results for each graduate student group - new matriculates (New), graduating MBAs (Grad), and alumni (Alum) - over the eight-year time horizon (once again, the reader is reminded that the class of 2000 represents the most recent alumni data available). 
Table 9

Comparative Rankings Of The Most Important Skill:

New Matriculates, Recent Graduates, And MBA Alumni

\begin{tabular}{|c|c|c|c|c|c|c|c|c|c|c|}
\hline Skill & & 1997 & 1998 & 1999 & 2000 & 2001 & 2002 & 2003 & 2004 & Ranking \\
\hline Critical Thinking & $\begin{array}{c}\text { New } \\
\text { Grad } \\
\text { Alum }\end{array}$ & $\begin{array}{l}1 \\
2 \\
1\end{array}$ & $\begin{array}{l}5 \\
1 \\
1\end{array}$ & $\begin{array}{c}2.5 \\
2 \\
1.5\end{array}$ & $\begin{array}{l}2 \\
2 \\
2\end{array}$ & $\begin{array}{l}1 \\
1\end{array}$ & $\begin{array}{l}1 \\
2\end{array}$ & $\begin{array}{c}1.5 \\
1\end{array}$ & $\begin{array}{l}3 \\
2\end{array}$ & $\begin{array}{l}1 \\
1 \\
1\end{array}$ \\
\hline Problem-Solving & $\begin{array}{c}\text { New } \\
\text { Grad } \\
\text { Alum }\end{array}$ & $\begin{array}{l}2 \\
1 \\
2 \\
\end{array}$ & $\begin{array}{l}1 \\
2 \\
2 \\
\end{array}$ & $\begin{array}{c}2.5 \\
1 \\
1.5\end{array}$ & $\begin{array}{l}1 \\
1 \\
1\end{array}$ & $\begin{array}{l}2 \\
2\end{array}$ & $\begin{array}{l}6 \\
1\end{array}$ & $\begin{array}{c}1.5 \\
2\end{array}$ & $\begin{array}{c}1.5 \\
1\end{array}$ & $\begin{array}{l}2 \\
2 \\
2\end{array}$ \\
\hline Interpersonal & $\begin{array}{c}\text { New } \\
\text { Grad } \\
\text { Alum }\end{array}$ & $\begin{array}{l}3 \\
4 \\
6\end{array}$ & $\begin{array}{c}2 \\
3.5 \\
5\end{array}$ & $\begin{array}{l}1 \\
4 \\
3\end{array}$ & $\begin{array}{c}4 \\
6 \\
4.5\end{array}$ & $\begin{array}{l}3 \\
8\end{array}$ & $\begin{array}{l}4 \\
3\end{array}$ & $\begin{array}{c}4 \\
3.5\end{array}$ & $\begin{array}{l}5 \\
4\end{array}$ & $\begin{array}{l}3 \\
3 \\
3\end{array}$ \\
\hline Team Building & $\begin{array}{c}\text { New } \\
\text { Grad } \\
\text { Alum }\end{array}$ & $\begin{array}{l}5 \\
3 \\
3 \\
\end{array}$ & $\begin{array}{c}4 \\
3.5 \\
3.5 \\
\end{array}$ & $\begin{array}{c}6 \\
8.5 \\
6.5 \\
\end{array}$ & $\begin{array}{l}7.5 \\
8.5 \\
7.5 \\
\end{array}$ & $\begin{array}{l}4 \\
3\end{array}$ & $\begin{array}{l}7 \\
4\end{array}$ & $\begin{array}{l}5 \\
7\end{array}$ & $\begin{array}{l}5 \\
3\end{array}$ & $\begin{array}{l}6 \\
4 \\
4\end{array}$ \\
\hline Quantitative & $\begin{array}{c}\text { New } \\
\text { Grad } \\
\text { Alum }\end{array}$ & $\begin{array}{c}5 \\
5.5 \\
4 \\
\end{array}$ & $\begin{array}{c}3 \\
5.5 \\
7 \\
\end{array}$ & $\begin{array}{l}4 \\
3 \\
5 \\
\end{array}$ & $\begin{array}{c}4 \\
3 \\
4.5 \\
\end{array}$ & $\begin{array}{c}5.5 \\
8\end{array}$ & $\begin{array}{l}3 \\
5\end{array}$ & $\begin{array}{c}6 \\
3.5\end{array}$ & $\begin{array}{c}5 \\
8.5\end{array}$ & $\begin{array}{c}5 \\
5 \\
5.5 \\
\end{array}$ \\
\hline Presentation & $\begin{array}{c}\text { New } \\
\text { Grad } \\
\text { Alum }\end{array}$ & $\begin{array}{l}5 \\
7 \\
6 \\
\end{array}$ & $\begin{array}{c}9 \\
7.5 \\
3.5 \\
\end{array}$ & $\begin{array}{c}8 \\
6 \\
8.5 \\
\end{array}$ & $\begin{array}{c}4 \\
4 \\
4.5 \\
\end{array}$ & $\begin{array}{c}5.5 \\
4\end{array}$ & $\begin{array}{l}2 \\
6\end{array}$ & $\begin{array}{l}3 \\
5\end{array}$ & $\begin{array}{c}1.5 \\
6\end{array}$ & $\begin{array}{c}4 \\
6 \\
5.5 \\
\end{array}$ \\
\hline Work Independently & $\begin{array}{c}\text { New } \\
\text { Grad } \\
\text { Alum }\end{array}$ & $\begin{array}{c}9 \\
5.5 \\
6\end{array}$ & $\begin{array}{c}7 \\
7.5 \\
9\end{array}$ & $\begin{array}{c}6 \\
5 \\
6.5\end{array}$ & $\begin{array}{c}7.5 \\
6 \\
4.5\end{array}$ & $\begin{array}{l}7 \\
8\end{array}$ & $\begin{array}{l}5 \\
8\end{array}$ & $\begin{array}{l}8 \\
7\end{array}$ & $\begin{array}{c}9 \\
8.5\end{array}$ & $\begin{array}{l}7 \\
7 \\
8\end{array}$ \\
\hline Writing & $\begin{array}{c}\text { New } \\
\text { Grad } \\
\text { Alum }\end{array}$ & $\begin{array}{c}7 \\
8.5 \\
8.5 \\
\end{array}$ & $\begin{array}{c}7 \\
5.5 \\
7 \\
\end{array}$ & $\begin{array}{c}9 \\
7 \\
8.5 \\
\end{array}$ & $\begin{array}{c}7.5 \\
8.5 \\
9 \\
\end{array}$ & $\begin{array}{c}8 \\
5.5\end{array}$ & $\begin{array}{l}9 \\
8\end{array}$ & $\begin{array}{l}7 \\
9\end{array}$ & $\begin{array}{c}7.5 \\
5\end{array}$ & $\begin{array}{l}8 \\
8 \\
9\end{array}$ \\
\hline Computer & $\begin{array}{c}\text { New } \\
\text { Grad } \\
\text { Alum }\end{array}$ & $\begin{array}{c}8 \\
8.5 \\
8.5\end{array}$ & $\begin{array}{l}7 \\
9 \\
7 \\
\end{array}$ & $\begin{array}{c}6 \\
8.5 \\
4 \\
\end{array}$ & $\begin{array}{c}7.5 \\
6 \\
7.5 \\
\end{array}$ & $\begin{array}{c}9 \\
5.5\end{array}$ & $\begin{array}{l}8 \\
8\end{array}$ & $\begin{array}{l}9 \\
7\end{array}$ & $\begin{array}{c}7.5 \\
7\end{array}$ & $\begin{array}{l}9 \\
9 \\
7\end{array}$ \\
\hline
\end{tabular}

Note: If two or more skills tie for a ranking, they are all given the average ranking that would have occurred had the scores differed by some small amount.

New MBA matriculates, recent MBA graduates, and MBA alumni were in clearly common agreement that in order of importance, Critical Thinking, Problem-Solving, and Interpersonal skills ranked 1-2-3. There was more tempered agreement with respect to the rankings of the other six skills displayed in Table 9. Note that new MBA matriculates have been assigning more weight to the importance of Presentation skills in recent years. Also, over the years 1997-2001, Interpersonal skills were generally rated higher by new MBA matriculates than by recent MBA graduates or MBA alumni. The value and importance of the nine critical skills to our three MBA respondent groups are integral to both the design and implementation of an MBA curriculum

Table 10 below provides an alternative view of the most important skills to the MBA student groups. Recall that new matriculates, recent graduates, and MBA alumni were all afforded an opportunity to identify the two most important skills. Aggregate percents who named each skill as being either first or second most important are presented in Table 10. For example, in 1997, 48.4\% of new matriculates identified Critical Thinking as either the first or second most important skill. 
Table 10

Importance of Specific Skills: Percent of Respondents Who Named Each Skill as 1st or 2nd Most Important

\begin{tabular}{|c|c|c|c|c|c|c|c|c|c|c|}
\hline Skill & & 1997 & 1998 & 1999 & 2000 & 2001 & 2002 & 2003 & 2004 & Totals \\
\hline Critical & New & $48.4 \%$ & $40.5 \%$ & $40.0 \%$ & $38.1 \%$ & $50.0 \%$ & $41.2 \%$ & $38.8 \%$ & $37.5 \%$ & $42.1 \%$ \\
\hline \multirow{2}{*}{ Thinking } & Grad & $43.2 \%$ & $50.8 \%$ & $48.7 \%$ & $58.7 \%$ & $61.9 \%$ & $47.2 \%$ & $40.9 \%$ & $51.0 \%$ & $50.6 \%$ \\
\hline & Alum & $43.7 \%$ & $39.6 \%$ & $58.0 \%$ & $41.0 \%$ & & & & & $44.9 \%$ \\
\hline \multirow{3}{*}{$\begin{array}{l}\text { Problem- } \\
\text { solving }\end{array}$} & New & $54.9 \%$ & $45.9 \%$ & $37.8 \%$ & $52.4 \%$ & $41.9 \%$ & $30.1 \%$ & $37.3 \%$ & $43.8 \%$ & $42.4 \%$ \\
\hline & Grad & $53.9 \%$ & $57.1 \%$ & $48.7 \%$ & $52.2 \%$ & $41.2 \%$ & $55.6 \%$ & $47.0 \%$ & $55.1 \%$ & $51.1 \%$ \\
\hline & Alum & $51.6 \%$ & $46.9 \%$ & $42.6 \%$ & $46.8 \%$ & & & & & $45.9 \%$ \\
\hline \multirow[t]{3}{*}{ Interpersonal } & New & $21.0 \%$ & $27.0 \%$ & $28.9 \%$ & $23.8 \%$ & $21.0 \%$ & $20.6 \%$ & $21.6 \%$ & $14.6 \%$ & $21.9 \%$ \\
\hline & Grad & $12.5 \%$ & $20.6 \%$ & $20.5 \%$ & $21.7 \%$ & $14.3 \%$ & $25.0 \%$ & $26.5 \%$ & $22.4 \%$ & $20.0 \%$ \\
\hline & Alum & $32.8 \%$ & $32.7 \%$ & $28.5 \%$ & $25.0 \%$ & & & & & $28.5 \%$ \\
\hline Team & New & $14.6 \%$ & $29.7 \%$ & $17.8 \%$ & $21.5 \%$ & $29.0 \%$ & $23.8 \%$ & $28.0 \%$ & $27.1 \%$ & $23.8 \%$ \\
\hline \multirow[t]{2}{*}{ Building } & Grad & $19.8 \%$ & $25.4 \%$ & $7.7 \%$ & $15.2 \%$ & $19.0 \%$ & $25.0 \%$ & $24.5 \%$ & $26.5 \%$ & $20.7 \%$ \\
\hline & Alum & $18.8 \%$ & $22.8 \%$ & $20.7 \%$ & $32.6 \%$ & & & & & $24.4 \%$ \\
\hline \multirow[t]{3}{*}{ Quantitative } & New & $11.3 \%$ & $18.9 \%$ & $22.2 \%$ & $14.3 \%$ & $14.5 \%$ & $28.6 \%$ & $13.9 \%$ & $18.7 \%$ & $17.6 \%$ \\
\hline & Grad & $21.6 \%$ & $14.3 \%$ & $30.8 \%$ & $17.4 \%$ & $12.7 \%$ & $11.1 \%$ & $20.4 \%$ & $6.1 \%$ & $16.5 \%$ \\
\hline & Alum & $22.3 \%$ & $11.3 \%$ & $18.0 \%$ & $9.6 \%$ & & & & & $14.2 \%$ \\
\hline \multirow[t]{3}{*}{ Presentation } & New & $17.8 \%$ & $16.2 \%$ & $17.8 \%$ & $23.8 \%$ & $17.8 \%$ & $30.1 \%$ & $24.8 \%$ & $31.3 \%$ & $22.6 \%$ \\
\hline & Grad & $12.7 \%$ & $11.1 \%$ & $17.9 \%$ & $10.8 \%$ & $25.3 \%$ & $25.0 \%$ & $22.5 \%$ & $24.5 \%$ & $18.5 \%$ \\
\hline & Alum & $19.0 \%$ & $21.2 \%$ & $15.5 \%$ & $21.9 \%$ & & & & & $19.3 \%$ \\
\hline Work & New & $6.4 \%$ & $5.4 \%$ & $13.3 \%$ & $4.8 \%$ & $4.8 \%$ & $11.1 \%$ & $12.4 \%$ & $4.2 \%$ & $8.0 \%$ \\
\hline \multirow[t]{2}{*}{ Independently } & Grad & $7.1 \%$ & $3.2 \%$ & $10.3 \%$ & $4.3 \%$ & $4.8 \%$ & $0.0 \%$ & $8.1 \%$ & $0.0 \%$ & $4.7 \%$ \\
\hline & Alum & $1.7 \%$ & $5.6 \%$ & $3.9 \%$ & $6.7 \%$ & & & & & $4.7 \%$ \\
\hline \multirow[t]{3}{*}{ Writing } & New & $6.5 \%$ & $5.4 \%$ & $6.6 \%$ & $14.3 \%$ & $9.7 \%$ & $6.4 \%$ & $14.0 \%$ & $12.6 \%$ & $9.4 \%$ \\
\hline & Grad & $12.7 \%$ & $4.8 \%$ & $7.7 \%$ & $10.9 \%$ & $12.7 \%$ & $8.3 \%$ & $2.0 \%$ & $8.2 \%$ & $8.5 \%$ \\
\hline & Alum & $5.2 \%$ & $11.4 \%$ & $6.5 \%$ & $7.7 \%$ & & & & & $7.6 \%$ \\
\hline \multirow[t]{3}{*}{ Computer } & New & $19.3 \%$ & $10.8 \%$ & $15.6 \%$ & $7.2 \%$ & $11.3 \%$ & $8.0 \%$ & $9.4 \%$ & $10.5 \%$ & $11.5 \%$ \\
\hline & Grad & $16.3 \%$ & $12.7 \%$ & $7.7 \%$ & $8.6 \%$ & $6.4 \%$ & $2.8 \%$ & $8.1 \%$ & $6.1 \%$ & $9.0 \%$ \\
\hline & Alum & $5.2 \%$ & $8.5 \%$ & $6.5 \%$ & $8.6 \%$ & & & & & $7.3 \%$ \\
\hline
\end{tabular}

The "Totals" column of Table 10 shows there is general agreement among the three groups on the importance of Team Building, Quantitative, Presentation, Writing, and Computer Skills. In the cases of Critical Thinking and Problem Solving skills the new students and the alums attached less importance to these skills than did the recent grads. This may be due to the fact that the recent grads have just completed their studies and have been concentrating more directly on these skills. The importance of Interpersonal skills shows greater agreement between the new students and recent grads with neither group having rated it as important as the alumni. This may reflect a maturing process in which as individuals advance in their organizations they find themselves in positions that require more interpersonal skills.

The trends over time are also interesting. A number of the skills have a fairly consistent pattern of importance over time. However, Computer skills appear to be declining in importance while Presentation and Team Building skills are increasing in importance. These trends have important implications for course design.

\section{CONCLUSIONS}

\section{Graduate Business Program Attributes}

The perceived quality attributes of our program are both attractive and important to all three respondent groups. In Table 2, new matriculates revealed that Program Reputation, Flexibility Taking Courses, and AACSB Accreditation were the first three most important reasons they chose our program. Recent graduates rated the quality of program attributes in Table 3 wherein Knowledge of Professors, Availability of Professors, Commitment of Faculty, and Overall Quality of Graduate Business Program placed 3rd through 6th respectively on a ranked list of 24 attributes. When MBA alumni were asked to list reasons they would recommend our program, Table 4 shows that 
Faculty Competence, Quality of Program, and Program Reputation placed 1st, 3rd, and 4th respectively, and Flexibility in Scheduling placed 5th. Quality of Program and Program Reputation were common themes rated very highly by all three MBA student groups. New students had not yet been exposed to faculty, but both graduating MBAs and MBA alumni rated the faculty extremely highly. These results are very comforting to the faculty and administration of the host college.

\section{Most Important Skills}

Overall, the ranking of the importance of skills is very consistent across the groups and over time. These skills can be conveniently grouped into three tiers that reflect their importance. Tier 1 , the highest ranked, consists of Critical Thinking and Problem Solving skills. Tier 2, the second highest ranked, includes Presentation, Team Building, Interpersonal and Quantitative skills. Finally Tier 3, the lowest ranked, is comprised of Writing, Computer, and Working Independently. The differences in ratings of most important skills across tiers are quite striking. For example, Table 10 shows that Tier 1 importance ratings were roughly twice as large as Tier 2, and Tier 2 ratings were about twice as large as Tier 3.

It is important to monitor these rankings over time since there are some trends that may well alter the importance of the skills. The low ratings of importance of Writing and Computer skills may have important implications for the way faculty present their courses and the amount of preparation they can expect from their students.

\section{Implications For Program Promotion}

In summary, the results of this study are encouraging to the College. We draw great satisfaction from what we consider to be mature views of our students and their commitment to skills improvement and career enhancement through our MBA Program. Knowledge of how newly matriculating MBA students, recent MBA graduates, and MBA alumni rate the importance of these skills should also provide direction for promotional campaigns and advertisements designed to attract new students. Clearly, our concentrations, courses, and curriculum themes should be emphasizing the development of Critical Thinking and Problem-Solving skills. With respect to program promotion themes, it appears that emphasis should be placed upon 25 years of uninterrupted AACSB accreditation, over 90 percent of faculty with terminal degrees, our excellent academic reputation, a close working relationship with the local business community, flexibility in course selection and sequencing, and the several areas of concentration available.

\section{REFERENCES}

1. AACSB Task Force on Outcome Measurement. (June, 1989). Report of the AACSB Task Force on Outcome Measurement.

2. AACSB International - The Association to Advance Collegiate Schools of Business International. (April, 2003, Revised January, 2004). Eligibility Procedures and Standards for Business Accreditation.

3. Joseph G. Glynn and Gregory R. Wood. MBA Alumni Ratings Of Critical Skills. Proceedings of the 2005 International Business \& Economics Research Conference, Las Vegas, October, 2005.

4. Joseph G. Glynn. MBA Student Pre-Program and Post-Program Assessment of Critical Skills: Implications for Outcomes Assessment and Curriculum Design. Journal of College Teaching \& Learning: Volume 2, Number 2, February, 2005.

5. Joseph G. Glynn. Expectations of Incoming MBA Students: Implications for Curriculum Development and Program Promotion. Journal of Business \& Economics Research: Volume 2, Number 2, February, 2004. 